\title{
Housing finance market and economic growth of West Africa region: a study of Nigeria and Ghana.
}

\author{
Ofor, T. N \\ Alagba O. S \\ Ifurueze, M.S \\ Department of Accountancy, Faculty of Management Sciences \\ Chukwuemeka Odumegu Ojukwu University \\ Anambra State, Nigeria
}

Keywords

Housing Finance, Mortgage Loan, Economic Growth, Capital

\begin{abstract}
The aim of this study is to investigate the effect of housing finance on economic growth of West African States while the specific objectives were to: analyse the contributions to housing finance by mortgage banks on the economic growth of Nigeria, examine the impact of aggregate housing finance on economic growth of Ghana among others. Secondary data were used, covering the period of study 1985-2014. The expost facto research design was adopted in this study. The data gathered were analysed using Ordinary Least Square Regression Method. The findings revealed that the housing finance markets in Nigeria and Ghana are under developed. The policy implication is that if urgent steps is not taken to address the housing needs of the region, more people are going to live in slumps. We recommend that the government of WA States should create an enabling environment to attract both local and foreign investors to invest in the housing sector.
\end{abstract}

Corresponding author: Alagba Ochuko S

Email address for corresponding author: emurovwo@gmail.com

First submission received: $6^{\text {th }}$ November 2018

Revised submission received: $19^{\text {th }}$ December 2018

Accepted: 24th December 2018

\section{Introduction}

Housing finance market is a formal institutional arrangement whereby individual, corporate entity and Developer obtain mortgage loan for the construction or purchase of a housing unit, shopping centers or Real Estate. The property is used as collateral for the loan applied for. Interest in the market is usually lower than what is obtainable in a conventional financial market and the time period ranges from ten years to thirty years duration.

One of the indices for accessing the level of economic growth of a nation is adequate housing. In a country where the majority of the people live in slum, such a country is classified as under - developed. The role of housing in growth and development is so vital that government all over the world make provisions for adequate housing of her citizens, the West African region inclusive. It has been argued that housing encompasses not only the physical building but include the available utilities and the siren environment, which make life comfortable (Boamah, 2010).

Several studies have revealed that the construction of a house is capital intensive and it represents the highest investment of most households. The consequence of the capital nature of housing is the shortage of affordable housing units throughout the countries of West African. It is estimated that Nigeria has a short fall of 17 million housing units and Ghana 1.7 million CAHF (2013). A robust housing finance 
market is needed across the region in order to meet these shortages of housing units. A dynamic housing finance market will supply the needed finance to individuals, corporate entities and developers. Housing is a long-time investment and the financing is usually beyond the reach of not only individuals but corporate entities and developers as well. Only a few proportions of the society can build a house of their choice out of personal income. Okonjor - Iwuala (2014), asserted that housing and housing finance has been a tool for rapid economic growth and development in the developed economies. This is due to its multiplier effects and interrelationship with other sector of the economy. The building of a single housing unit is capable of providing employment for over 10 people. These include architect, structural engineer, bricklayer, meson electrician, plumber, building material dealers etc.

The huge housing units' deficits in West Africa, Nigeria and Ghana inclusive is an indication of the investment potentials in the sector. A proper harnessing of these potentials will place the region on the part of sustainable economic growth. It is in line with these that the general objective of this studies is to determine the effect of housing finance market on growth of West Africa region, while the specific objectives are to:

- Examine the effect of the contributions to housing finance by commercial banks on economic growth of Nigeria.

- determine the effect of the aggregate housing finance on economic growth of Ghana The novelty of this research could be seen from the following angles:

Firstly, there are few studies on housing finance market in West Africa and secondly, most of these researches are on access to housing finance by small and medium income earners. Generally, there is no studies on the impact of housing finance market on economic growth of West Africa region, hence this study.

\section{Review of Related Literature}

According to Aigbokhan (1995), Economic growth means an increase in the average rate of output produce per person usually measured on a per annum basis. It is also the rate of change in national output or income in a given period. Economic growth is the increase of per capita gross domestic product (GDP) or other measure of aggregate income. It is often measured as the rate of change in real GDP. Economic growth refers only to the increase in the quantity of goods and services produced. Gujarati (2002) defines economic growth as an increase in real gross domestic product (GDP). That is, gross domestic product adjusted for inflation. The growth can either be positive or negative. Negative growth can be referred to by saying that the economy is shrinking. This is characterized with economic recession and economic depression. Ullah and Rauf (2013) noted that whenever there is increase in real GDP of a country it will boosts up the overall output and we called it economic growth. The economic growth is helpful to increase the incomes of the society, help the nation to bring the unemployment at low level and also helpful in the deliveries of public services.

The role of housing finance in the acceleration of economic growth of nations has been acknowledged worldwide, especially in the developed economics. IMF (2011) posits that the importance of housing finance could be seen through housing market booms usually "followed by busts have been associated with financial instability and significant costs to the economy in many countries over the years". They argued that the global financial crisis of 2007-2009 was occasioned by excessive subprime lending in the US. The crises quickly spread to other parts of the world such as Ireland, United Kingdom and Spain, causing financial instability.

Likewise, Reinhart and Rogott (2009) showed that the six major historical episodes of banking crisis in advanced economies since the mid - 1970s were all associated with a housing boost. They document that this pattern can also be found in many emerging market crises, including the Asian financial crisis of 
1977-98, with the magnitude of house price decline being broadly similar in both advance and emerging market economies.

Weiss and Jones (2017), argued that the decision to purchase a home by individual families is dependent on their financial standing. They argued that only few households can purchase a home with their personal income. Majority will take a mortgage. Furthermore, a loan on mortgage is obtained in the primary market while the secondary market is the market for buying and selling mortgages, such as mortgage-Back securities (MBS). Given the strategic position occupied by housing finance in the U.S economy, congress is interested in the activities in the housing finance market.

Furthermore, Oyalowo (2012), examined the constraints limiting lending institutions' participation in finance supply in West Africa region. It also examined how governments across West Africa can tackle these constraints. The study used a regression analysis of secondary data related to factors necessary for lending institutions' participation in formal housing finance supply. The ratio of the private credit to GDP of West Africa countries between 2008 and 2010 was regressed against the independent variables, inflation rate, procedure to register property, time to register property, cost of registering property, strength of legal right index and dept. of credit information system. Similarly, Isa, Jimoh and Achuuenu (2013), posits that the housing sector has a multiplier effect. In most developed economies, the housing sector is seen as an important sector for stimulating economic growth.

According to CAHF (2015), housing finance markets are developing in scale and diversity across Africa, creating opportunity for investors and practitioners, and promoting a new category for economic growth. One of the factors responsible for the growth of the market is growth in population and ruralurban migration. Consequently, the growth in population in many cities in West African countries has created demand for new housing. Hence West African housing finance markets is said to be dynamic and growing.

HFPC (2018), studied the impact of raising interest rate on the USA mortgage market. Primary mortgage market survey (PMMS) carried out by Freddie Mac in October 2018 showed that the interest rate has gone up to 4.9 percent; the highest rate ever recorded since 2010 . The consequences of the high interest rate are that the number of borrowers who are able to save money by refinancing their housing loans has reduced. The refinance share of all the three major financing agencies as at September 2018 were Fannie Mae 32 percent, Freddie Mac 26.5 percent and Ginnie Mae 20.8 percent. This has implication, as the contribution of the housing finance to the growth of the U.S economy will drop; they argued.

Yinusa, Ilo and Elumah (2017), asserted that housing is a basic necessity of man. However, the effect of the financial sector has not been significant in Nigeria. A study on the contributions of microfinance banks loans to housing, primary mortgage Banks loans to housing and Governments budgetary allocation to housing were insignificant to housing development in Nigeria. Hence, they concluded that with the huge opportunity in the housing sector. Government should embark on massive enlightenment campaign on the need of housing provision.

\subsection{Methodology}

The data for this study were drawn from Central Bank of Nigeria Statistical Bulletin, World Bank data base and Centre for Affordable Housing Finance in Africa - Africa Housing Finance year- books 2013 and 2015. The ex-post facto research design method was adapted in this research the study covers a period of thirty years, 1985 to 2014.

\section{Justification for Central Bank Data}

The Central bank is the apex bank which regulate the activities of other banks in Nigeria. All the banking institutions submit monthly, quarterly and annual report of their operations to the Central bank. 
Hence data from Central bank are officially recognized by the Nigerian government, International agencies and researchers.

\section{Model specification}

This work is modeled after Oyalowo (2012) who studied housing market constraints in West African Region. The classical linear regression method was employed in the analysis of data which according to Gujarati and Porter (2009) is stated thus:

$$
\begin{aligned}
& Y=a_{o}+a_{1} X_{1 t}+a_{2} X_{2 t}+\ldots a_{n} X_{n t}+e_{t} \\
& \text { Where } Y=\text { Dependent variables } \\
& \text {..... eqn (1) } \\
& \mathrm{a}_{\mathrm{o}}=\text { Intercept } \\
& \mathrm{a}_{1}, \mathrm{a}_{2}, \ldots \mathrm{a}_{\mathrm{n}}=\quad \text { Scope or co-efficient of the parameter estimates } \\
& \mathrm{X}_{1} \mathrm{X}_{2} \mathrm{X}_{\mathrm{n}}=\text { Independent variables } \\
& \text { e } \quad=\quad \text { Stochastic error term }
\end{aligned}
$$

The generalized model for this study is written thus:

$$
\triangle \mathrm{RGDP}_{\mathrm{t}}=\mathrm{a}_{0}+\mathrm{a}_{1} \mathrm{MHFK}_{\mathrm{t}}+\mathrm{a}_{2} \mathrm{CHFK}_{\mathrm{t}}+\mathrm{a}_{3} \mathrm{IR}_{\mathrm{t}}+\mathrm{e}_{\mathrm{t}} \quad \text {---- eq(2) }
$$

Where $\quad \Delta R G D P_{t}=$ change in Real GDP which is a proxy for economic growth

$\mathrm{a}_{\mathrm{o}}=$ Intercept

$a_{1}, a_{2}, a_{3}=$ Scope of or co-efficient of the parameter estimates

MHFK $_{\mathrm{t}}=$ Mortgage Housing Finance in Nigeria

$\mathrm{CHFK}_{\mathrm{t}}=$ Commercial Bank Housing Finance in Nigeria

$\mathrm{IR}_{\mathrm{t}}=\quad$ Interest rate used as a control variable

$\mathrm{e}_{\mathrm{t}} \quad=\quad$ error term

The model is disaggregated to be able to test all the hypotheses and it will be rewritten thus:

Hypotheses 1 and 2

$\Delta \mathrm{RGDP}_{\mathrm{Nt}}=\mathrm{a}_{\mathrm{o}}+\mathrm{a}_{1} \mathrm{MBOHL}_{\mathrm{Nt}}+\mathrm{a}_{2} \mathrm{CBOHL}_{\mathrm{Nt}}+\mathrm{a}_{3} \mathrm{IR}_{\mathrm{t}}+\mathrm{e}_{\mathrm{t}}$

None inclusion of Ghana in the Model

Ghana was excluded from the model due to non-availability of sufficient quantitative data. Consequently, research questions were used in discussing housing finance in Ghana.

\subsection{Data Presentation and Interpretation}

Table 1: Nigeria Housing Loans and Other Variables under Study (N-Billions) 1985 - 2014

$\begin{array}{llllllrrr}\text { YEAR } & \text { TOL } & \text { TOCBL } & \text { CBOHL } & \text { MBOHL } & \text { TOHL } & \text { GDP } & \text { THLPTL } & \text { THLPGP } \\ & & & & & & & \\ 1985 & 12.17020 & 12.17020 & 2.493700 & 0.000000 & 2.493700 & 134.5856 & 20.49021 & 1.852873 \\ 1986 & 15.70160 & 15.70160 & 2.840400 & 0.000000 & 2.840400 & 134.6033 & 18.08988 & 2.110201 \\ 1987 & 17.53190 & 17.53190 & 2.892400 & 0.000000 & 2.892400 & 193.1262 & 16.49793 & 1.497674 \\ 1988 & 19.56120 & 19.56120 & 3.007900 & 0.000000 & 3.007900 & 263.2945 & 15.37687 & 1.142409 \\ 1989 & 22.00800 & 22.00800 & 3.226700 & 0.000000 & 3.226700 & 382.2615 & 14.66149 & 0.844108 \\ 1990 & 26.00010 & 26.00010 & 3.210800 & 0.000000 & 3.210800 & 328.6061 & 12.34918 & 0.977097 \\ 1991 & 31.30620 & 31.30620 & 3.573200 & 0.000000 & 3.573200 & 545.6724 & 11.41371 & 0.654825 \\ 1992 & 42.94570 & 42.73680 & 4.059400 & 0.208900 & 4.268300 & 875.3425 & 9.938830 & 0.487615 \\ 1993 & 66.00000 & 65.66530 & 5.405200 & 0.334700 & 5.739900 & 1089.680 & 8.696818 & 0.526751 \\ 1994 & 94.74420 & 94.18390 & 0.000000 & 0.560300 & 0.560300 & 1399.703 & 0.591382 & 0.040030 \\ 1995 & 144.9645 & 144.5696 & 0.000000 & 0.394900 & 0.394900 & 2907.358 & 0.272412 & 0.013583 \\ 1996 & 170.1919 & 169.4371 & 0.000000 & 0.754800 & 0.754800 & 4032.300 & 0.443499 & 0.018719 \\ 1997 & 386.2885 & 385.5505 & 0.000000 & 0.738000 & 0.738000 & 4189.250 & 0.191049 & 0.017617\end{array}$




$\begin{array}{rrrrrrrrr}1998 & 273.6814 & 272.8955 & 0.000000 & 0.785900 & 0.785900 & 3989.450 & 0.287159 & 0.019699 \\ 1999 & 323.6891 & 322.7649 & 0.000000 & 0.924200 & 0.924200 & 4679.212 & 0.285521 & 0.019751 \\ 2000 & 509.1573 & 508.3022 & 0.000000 & 0.855050 & 0.855050 & 6713.575 & 0.167934 & 0.012736 \\ 2001 & 797.1894 & 796.1648 & 0.000000 & 1.024646 & 1.024646 & 6895.198 & 0.128532 & 0.014860 \\ 2002 & 961.2294 & 954.6288 & 0.000000 & 6.600618 & 6.600618 & 7795.758 & 0.686685 & 0.084669 \\ 2003 & 1222.929 & 1210.033 & 0.000000 & 12.89556 & 12.89556 & 9913.518 & 1.054481 & 0.130081 \\ 2004 & 1525.243 & 1519.243 & 0.000000 & 6.000000 & 6.000000 & 11411.07 & 0.393380 & 0.052581 \\ 2005 & 1978.811 & 1976.711 & 0.000000 & 2.100000 & 2.100000 & 14610.88 & 0.106124 & 0.014373 \\ 2006 & 2531.858 & 2524.298 & 0.000000 & 7.560000 & 7.560000 & 18564.59 & 0.298595 & 0.040723 \\ 2007 & 4854.248 & 4813.489 & 0.000000 & 40.75940 & 40.75940 & 20657.32 & 0.839665 & 0.197312 \\ 2008 & 7907.932 & 7799.400 & 466.8007 & 108.5315 & 575.3322 & 24296.33 & 7.275382 & 2.367980 \\ 2009 & 9030.730 & 8912.143 & 778.1404 & 118.5869 & 896.7273 & 24794.24 & 9.929733 & 3.616676 \\ 2010 & 7839.307 & 7706.430 & 670.3048 & 132.8761 & 803.1809 & 33984.75 & 10.24556 & 2.363357 \\ 2011 & 7435.539 & 7312.726 & 453.5036 & 122.8128 & 576.3164 & 37409.86 & 7.750836 & 1.540547 \\ 2012 & 8270.936 & 8150.030 & 539.7598 & 120.9054 & 660.6652 & 40544.10 & 7.987792 & 1.629498 \\ 2013 & 10137.89 & 10005.59 & 726.9216 & 132.2917 & 859.2133 & 42396.77 & 8.475271 & 2.026601 \\ 2014 & 12937.10 & 12889.42 & 556.1929 & 47.68000 & 603.8729 & 44507.88 & 4.667760 & 1.356777\end{array}$

Sources:2014 Monthly Bulletin, Central Bank of Nigeria - Statistical Bulletin 2014

The World Bank: http://data.worldbank.org

Centre for Affordable Housing Finance in Africa-Africa Housing Finance Yearbook 2012, 2013 and 2015

Data presented on table 1 are housing finance data on Nigeria Economy. The data are total outstanding loans and the component for the housing sector in Nigeria. These loans are presented in billion of Naira. Data were sourced mainly from central bank of Nigeria statistical bulletin. Similarly, GDP was sourced from Central Bank of Nigeria statistical bulletin. Data on table 1 showed that mortgage banks started reporting their financial transactions from 1992, even though mortgage banking started in Nigeria in 1977. Data were available from 1997 - 2014, a period of 23 years out of 30 years (1985-2014) which is the study period.

The table further revealed that in 1992 the mortgage banks outstanding housing loans amounted to 0.208900 billon Naira which translates to 0.49 percent of total outstanding loans and 0.024 percent of GDP respectively. From available data on table 1, it could be argued that commercial banks are the major participants in the housing finance market in Nigeria. Also, the share of outstanding mortgage loans by commercial banks appears to be very small when compared to total outstanding loan as shown on column 4 , table 1. Column 4 (CBOHL) revealed that out of 30 years under study, commercial banks did not lend to the housing sector for a period of fourteen (14) years (1994- 2007).

For the period 1985 - 1993 and 2008 - 2014, which amounted to sixteen (16) years out of the thirty (30) years study period, commercial banks participated in the housing finance market. During this period housing finance contribution to GDP average 1.68 percent; a figure too small when compared to other African nations with a robust mortgage finance markets, such as South Africa 36 percent, Namibia 22 percent and Morocco 18 percent. 
Table 2: Nigeria, Descriptive Statistics of Housing Loans and other Variables under Study in Nigeria

$\begin{array}{lllll} & \text { LNRGDP } & \text { LNMBOHL } & \text { LNCBOHL } & \text { LNTHLPGP } \\ \text { Mean } & 5.361345 & 1.748246 & 3.465593 & -1.453794 \\ \text { Median } & 5.288628 & 1.791759 & 1.544198 & -0.679628 \\ \text { Maximum } & 5.828497 & 4.889417 & 6.656907 & 1.285555 \\ \text { Minimum } & 4.904583 & -1.565900 & 0.913768 & -4.363312 \\ \text { Std. Dev. } & 0.280466 & 2.336723 & 2.659163 & 2.045743 \\ \text { Skewness } & 0.296004 & 0.197940 & 0.248100 & -0.234739 \\ \text { Kurtosis } & 1.831747 & 1.455706 & 1.086687 & 1.387385 \\ \text { Jarque-Bera } & 2.144111 & 2.435665 & 2.604653 & 3.526171 \\ \text { Probability } & 0.0342304 & 0.0295871 & 0.0271898 & 0.171515 \\ \text { Sum } & 160.8403 & 40.20966 & 55.44948 & -43.61383 \\ \text { Sum Sq. Dev. } & 2.281181 & 120.1260 & 106.0672 & 121.3669 \\ \text { Observations } & 30 & 23 & 16 & 30\end{array}$

Source: Author's Eviews Computation (2017)

The descriptive statistics in Table 2 above shows the aggregated averages of mean, median and mode for all the observations. The dispersion and variations in the series are shown by the standard deviation while the degree of pointedness and degree of departure from symmetry are shown by kurtosis and skewness respectively. A combined test of skewness and kurtosis known as Jacque- Bera Statistics which test for normality is also shown in the table above and the result shows that most of the variables are normally distributed with the exception of LNTHLPGP having the highest JB statistic and a p-value 0.17. This means that any variable with outlier are not likely to distort our conclusion and are therefore reliable for drawing generalization. Also, none of the kurtosis value is greater than 3 showing evidence of platykurtosis. However, it can be observed that all the variables have kurtosis of less than 3, suggesting a departure from normality, though this is not a problem with financial time series.

Fig 1: Nigeria Housing Loans and other Variables Under Study (Billons of Naira) 1985-2014

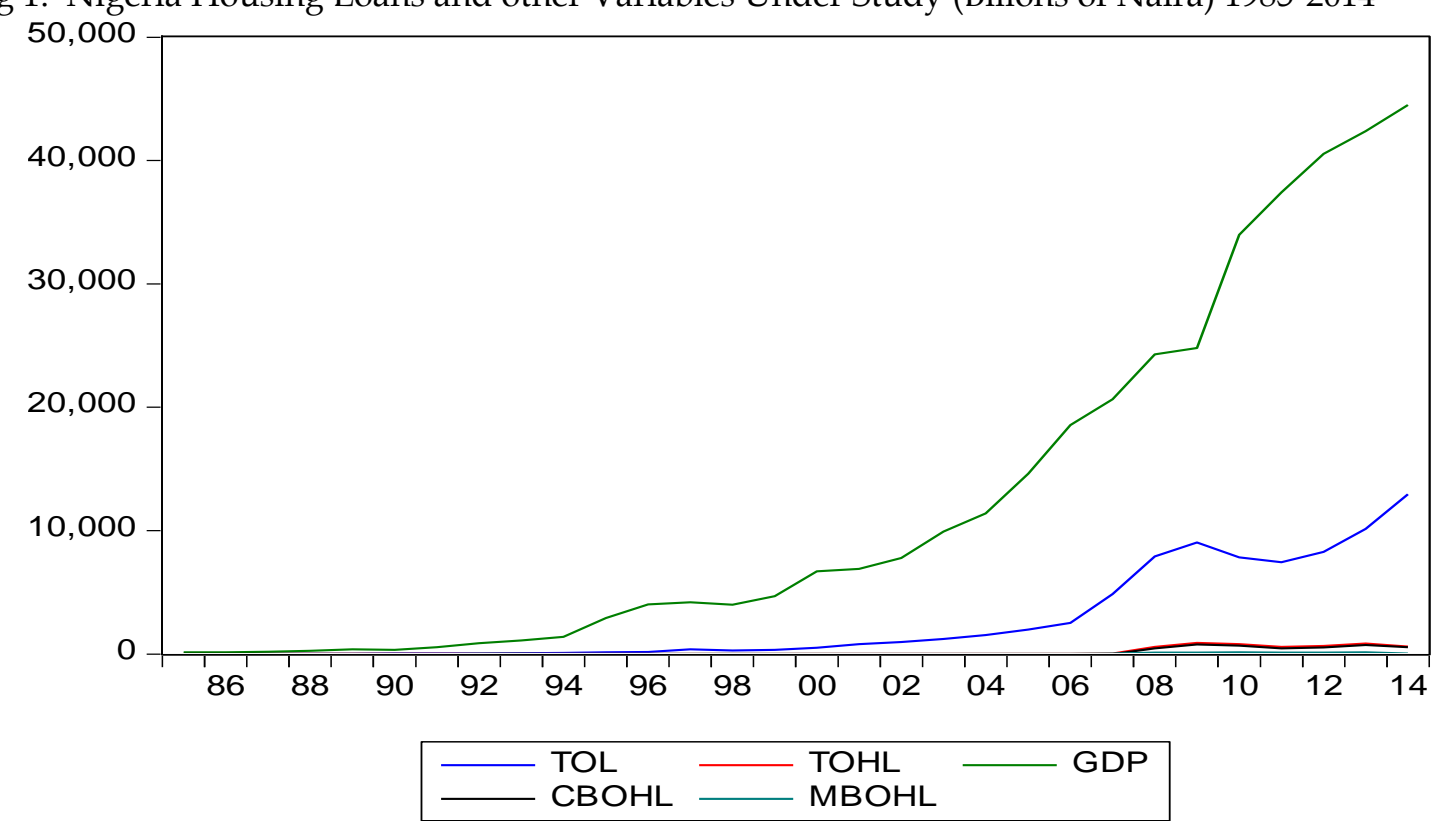


The above graph (fig 1), shows the housing finance data movement in Nigeria. While the GDP moved slowly from 1985 to 1989, it started rising from 1990 and got to its peak in 2014. The slope of the total outstanding loans was below that of the GDP with a wide margin, indicating the extent of the financial sector contribution to economic growth. The slope of CBOHL only rose above the horizontal line in 2008, indicating that the impact of contributions to housing finance by commercial banks on economic growth of Nigeria is zero. The contributions of mortgage banks could be said to be almost non-existence.

Table 3: Stationarity Tests of the Key Variables

\begin{tabular}{|c|c|c|c|c|c|}
\hline Variable & ADF Stat & Critical & Value & P. Value & Order of integration \\
\hline LNMBOHL & -4.0215 & -3.6584 & & 0.0253 & $\mathrm{I}(1)$ \\
\hline LNCBOHL & -6.5501 & -4.0081 & & 0.0025 & I (1) \\
\hline LNRGDP & -6.2810 & -3.5950 & & 0.0001 & I (1) \\
\hline LNTHLPGDP & -4.2121 & -3.5875 & & 0.0133 & I (1) \\
\hline
\end{tabular}

Source: Author's Eviews Computation

From Table 3, we discover that the variables are integrated of the same order as they are all stationary at first difference. This is so because at first difference, the ADF stat for all the variables are more negative than the critical values at $5 \%$ and their corresponding probability value are all less than $5 \%$. It is on this premise that the null hypothesis of the presence of unit root is rejected and the alternative accepted.

\subsection{Test of Hypotheses one and two}

Step One: Restating of the Hypotheses in Null Form

$\mathrm{Ho}_{1}$ : The contribution of housing finance by Mortgage banks does not have a significant effect on economic growth of Nigeria.

$\mathrm{Ho}_{2}$ : The contribution of housing finance by Commercial banks does not have a significant effect on economic growth of Nigeria

Test Statistics: Ordinary least square with other diagnostics tests

\section{Table 4:}

Regression Results Test of the Model Formulated

Dependent Variable: LNRGDP

Method: Least Squares

Date: 07/25/16 Time: 21:11

Sample (adjusted): 19922014

Included observations: 30

\begin{tabular}{lcccc}
\hline \hline Variable & Coefficient & Std. Error & t-Statistic & Prob. \\
\hline \hline C & 5.323074 & 0.340735 & 15.62232 & 0.0000 \\
LNMBOHL & 0.115620 & 0.097772 & 1.182550 & 0.2902 \\
LNCBOHL & 0.000771 & 0.122504 & 0.006291 & 0.9952 \\
LNTHLPGP & -0.163188 & 0.131174 & -1.244057 & 0.2686 \\
\hline \hline
\end{tabular}




\begin{tabular}{llll} 
R-squared & 0.888235 & Mean dependent var & 5.648245 \\
Adjusted R-squared & 0.821176 & S.D. dependent var & 0.225668 \\
S.E. of regression & 0.095430 & Akaike info criterion & -1.559755 \\
Sum squared resid & 0.045534 & Schwarz criterion & -1.472100 \\
Log likelihood & 11.01890 & Hannan-Quinn criter. & -1.748915 \\
F-statistic & 13.24559 & Durbin-Watson stat & 2.306597 \\
Prob(F-statistic) & 0.008160 & & \\
\hline \hline
\end{tabular}

Source: Author Eview's Computation (2017)

From table 4, Economic Growth is proxy as Real Gross Domestic Product (RGDP) while Mortgage Banks contribution to Housing finance is proxy as Mortgage Banks Outstanding Housing Loan (MBOHL) and Commercial Banks contribution to Housing finance is proxy as Commercial Banks Outstanding Housing Loan (CBOHL), Ratio of Total Housing Loan to Total Loan (THLPTL) is used as control variable. From the regression result in the table LNMBOHL shares a positive and none statistically significant relationship with RGDP as the coefficient is positive (0.115620) and the p-value is greater than 5\% (0.2902). LNCBOHL shares a positive but not statistically significant relationship with RGDP as the coefficient is positive $(0.000771)$ and the $\mathrm{p}$-value is greater than $5 \%(0.9952)$.

Step Three: Diagnosis of the Regression Result of Model one and two

From the result shown above, the $\mathrm{R}^{2}$ is $89 \%$ indicating that the independent variables account for $89 \%$ of the variation in RGDP while $11 \%$ of the variation is explained by factors outside the model. The $\mathrm{F}$ statistic also shows that the overall regression is statistically significant and can be used for meaningful analyses. This is shown by the p-value that is less than $5 \%$ (0.008). The Durbin Watson Stat. which is 2.3 is approximately 2 showing that there is no evidence of autocorrelation. Essentially, the regression is good enough for the test of the set hypotheses.

Step Four: Decision for Hypotheses one and two

Given the fact that the p-values of the t-statistics in hypotheses one and two are all greater than $5 \%$, we refuse to accept the null hypotheses and conclude that both Mortgage Banks and Commercial Banks contribution to Housing finance do not have significant impact on economic growth in Nigeria.

\section{Discussion of Findings and Conclusion}

\subsection{Discussion of Findings}

Objective one: To determine the effect of the contributions to housing finance by mortgage banks on the Economic growth of Nigeria.

From the regression result in table 4, LNMBOHL was found to have a positive and not statistically significant effect on RGDP as the coefficient is positive (0.115620) and the P-value is greater than $5 \%$ (0.2902). Mortgage banking as a strategy for housing delivery and economic growth has been in operation in most developed countries as early as 1930s. In Nigeria mortgage banking started with the establishment of the Nigerian Building Society in 1956 by the colonial government (Olaniran, 2003; Osibogun, 2016).

Even though mortgage banking started in Nigeria as far back in 1956, table 1 and fig. 1 reveals that activities of the market only came to the fore in 1992. The value of loans granted by the market in the year 1992 amounted to only N0.2089 billion. The low market performance continued until 2001, when for the first time the market granted loans of N1 billion. Given the capital-intensive nature of housing, it is evident that N1 billion can only afford few numbers of housing units. 
Trend analysis of outstanding mortgage loans by mortgage banks as depicted in fig. 1 reveals that the effect of the contributions to housing finance by mortgage banks on the economic growth of Nigeria is less than one percent on yearly average throughout the period under study. These findings correspond with the findings of similar studies carried out by Osibogun (2016), Akenju (2007) and Oyalowo (2012). Hence, we concluded that objective one has been achieved.

Objective two: To ascertain the effect of the contributions to housing finance by commercial banks on the economic growth of Nigeria.

From table 4, Economic growth is proxy as Real Gross Domestic product (RGDP) while commercial banks contribution to housing finance is proxy as commercial banks outstanding housing loans (CBOHL), while ratio of total housing loan to total loans (THLPTL) is used as control variable. From the regression result LNCBOHL has a positive but not statistically significant effect on RGDP as the coefficient is positive (0.000771) and the P-value is greater than 5\% (0.9952).

Based on the evidence on table 1 and fig 1, it could be argued that commercial banks are the main sources of fund to the housing finance market in Nigeria and this might be as a result of the federal government directives on commercial banks through the Central Bank of Nigeria to allocate a minimum of 5 percent of their total loan portfolio to the housing sector.

For the period under review the contribution of both mortgage banks and commercial banks to economic growth of Nigeria ranges between 0.0127 percent and 3.6167 percent. In 1985 it was 1.8529 percent and declined to 0.0127 in 2000, and thereafter increased to 3.6167 (the highest) in 2009. It further decreased in 2014 to 1.3569 percent. These findings are in line with the findings of 1sa, Jimoh and Achuenu (2013), Oyalowo (2012), Sanusi (2003) and CAHF (2015) who carried out similar studies. Given the inter-relationship of the findings, it is evident that objective two has been achieved.

\section{Ghana}

Aggregate Housing Finance Market and Economic Growth of Ghana

It has been observed that the housing finance market in Ghana is grossly underdeveloped. This is attributable to the unstable political climate of the early 1980s, which crippled the housing finance market in Ghana, as people were afraid to build. Similarly, these years were also characterized by government lack of adequate resources to fund the housing sector. One of the sources of pride to the average Ghanaian is the ability to own a house which is considered more important than education and health. Housing is seen as a reflection of one's social status (Boamah, 2010).

According to Ghana Real Estate Developers Association (GREDA) (1998), the poverty level in the country is so high that only $5 \%$ of the citizens that are interested in building a house can do so from their own income. While $60 \%$ would need mortgage finance and the remaining $35 \%$ will not be able to own a house in their life time. This ascertain is collaborated by the findings of Boamah (2010) who studied housing affordability in Ghana with a focus on Kumasi and Tamale. He noted that high premium is put on home ownership in Ghana, however a greater proportion of the household in Kumasi and Tamale are incapable of acquiring a house with their own earned income or owning a house in their life time.

The size of the housing finance market is so small that its impact is barely felt. The ratio of outstanding mortgage loan to GDP was 2.5\% in 2004, 3.9\% in 2006 and 0.50\% in 2015 (Bank of Ghana, 2007, CAHF, 2015 Rust 2012). Ghana has 26 commercial banks, out of which only 5 officially offer mortgage loans as a product. The banks are HFC, Fedelity, Calbank, Stanbic and UT bank. The country's only non - bank institution which concentrate exclusively on lending for residential mortgage is Ghana Home Loans (GHL). Our findings revealed that less than 3\% of total loans granted by banks goes into housing finance. An indication that the market is under developed when compared on regional and continental basis. 
It has been argued that the formal financial institutions made minimal contribution to housing delivery in Ghana. Between 90 - 92\% of houses build are constructed through self-help and on incrementally basis. This is referred to as sweat equity (in Ghanaian Parlance). Sometimes the construction of a house takes between 5 to 15 years and by the time it is completed it is already out of time with modern reality (Nelson and Asamoah, 2014; CAHF, 2016).

According to Bank of Ghana (2007), the dearth of quantitative housing data in Ghana is associated with the nature of funding housing construction model in Ghana. The model which is based on personal savings, borrowing from friends, relatives and cooperative societies, is slow and prolong the construction period of a house. Conversely, the economic values on incremental bases are not capture in the Gross National Income (GNI) accounting of the country. The inability to correctly record activities in the housing market is a barrier to the growth of the market. Rust (2012), posits that "because the mortgage market is so small, current housing investment in the market is so small, current housing investment in Africa countries is not well quantified". Furthermore, housing construction in Ghana is driven by household rather than developers or government. Government effort aimed at housing delivery is directed toward the civil servants who are usually allocated land in areas which lack basic amenities such as good access road, electricity and pipe bore water. While the housing finance market only serve the needs of the few members of the society within the high-income bracket.

For housing to play its role in the growth and development agenda, it must be accessible to the majority of the people. Boamah (2014) puts it thus, "access to affordable and sustainable housing fund is extremely essential for the provision of adequate shelter for the citizen of a country". Likewise, Nelson and Asamoah (2014), noted that the mortgage market is used to meet the housing need of people in the developed economies. However, the reverse is the case in the developing countries such as Ghana where the mortgage market is accessible to less than $30 \%$ of the working populace. These inhibitions suggest that the housing finance market in Ghana is not in position to impact positively and significantly to the economic growth in Ghana. However, given the 1.7 million housing units deficit, the Ghanaian housing market will require a minimum of 3.4billion Dollars for new housing construction in order to bridge the housing deficit gap. If the above amount is invested into the Ghanaian economy, it is capable of transforming the economy while at the same time placing it on the path of sustainable economic growth and development.

\subsection{Conclusion}

Generally, the housing finance market in West African is under-developed. The huge investment opportunities in the market have not been explioted due to the small size of the mortgage market. Nigeria has the largest housing finance market in the region but its impact on economic growth is not statistically significant. It implies that despite the large size of the market, it is still under-developed.

Some other housing finance markets in the region are worst hit as a result of wide spread poverty. Other constrain to the growth of the market in the region include but not limited to poor salary / wages paid to the average worker, high interest lending rate, land tenure system, high cost of formalizing title to land and the cumbersome processes involved in obtaining title document to land. In some cases, it takes up to three years.

\subsection{Recommendations}

In order to allow housing finance to play its developmental roles as obtainable in developed economies we recommend the followings:

- The various governments of West African State should introduce policies that would make both mortgage and commercial banks increase their housing sponsorship in West Africa. 
- The high cost of land should be addressed with a view to making it affordable to those who are ready to build houses and at low interest rate too.

- The private sector should be encouraged to utilize the huge opportunities that abound in the housing and housing finance by investing in the sector.

\section{Research Limitations and Direction for Further Research \\ 4.1 Research Limitation}

The major challenge faced during the course of this study is availability of data on mortgage financing in Ghana. However, this problem was managed by not including Ghana in our model specification.

\subsection{Suggestion for Further Study}

Based on the result of this study, we therefore suggest that further study should be carried out on this area, expanding the scope to other African countries not covered in this study.

\section{References}

Akeju, A.A. (2007). Challenges to providing affordable housing in Nigeria. A paper presented at the $2^{\text {nd }}$ Emerging ultra-Africa international conference on Housing Finance in Nigeria, held at SehuYar'adua Center Abuja, Nigeria.

Afrane, S.K., Owusu-Manu, D., Donkor-Hyiaman, K.A., \& Bondinuba, F.K. (2014). Toward innovative housing financing in Ghana: an evidence based from South Africa's pension housing financing system. Journal of policy and administrative research 4(4): $97-110$.

Bank of Ghana (2007). The housing market in Ghana. Research department bank of Ghana.

Bensouda, A. \& Co, LP (2013). Improving land sector governance in the Gambia. Implementation of the land governance assessment framework (LGAF). Kanifing Institutional Area Kanifing Munipality.

Boamah, N.A. (2010). Housing Affordability in Ghana: a focus on Kumasi and Tamale. Ethiopian journal of environmental studies and management, 3(3): $1-11$.

Boamah, N.A. (2014). Housing policy in Ghana: the feasible paths. GJDS, 11 (1).

Centre for Affordable Housing Finance in Africa (CAHF, 2013). Housing Finance in Africa year book: a review of some of Africa's housing finance markets. Parkview, South Africa Centre for Affordable Housing Finance in Africa, a division of Fin-Mark Trust.

Centre for Affordable Housing Finance in Africa (CAHF, 2015). Housing Finance in Africa year book: a review of some of Africa's housing finance markets. Parkview, South Africa Centre for Affordable Housing Finance in Africa, a division of Fin-Mark Trust.

Centre for Affordable Housing Finance in Africa (CAHF, 2016). Understanding Ghana housing finance market.

Harris, S.C. (2014). Investment climate statement. U.S Department of State: 1 - 19.

Hatfield, J.P. (2016). Innovation Affordable housing practices in Africa: cement block banking in the Gambia.Case study series 3. Centre for Affordable Housing Finance in Africa

Housing Finance policy center (HPPC 2018). Housing finance at a glance, a monthly chartbook, Urban institute elevate the debate

Isa, K.B., Jimoh, R.A., and Achuenu (2013). An overview of the contribution of construction sector to sustainable development in Nigeria. Net Journal of Business Management, 1(1), 1 - 6.

Nelson, I.D., Asamoah, R.O. (2014). Participation of real estate development in mortgage financing: push and pull factors in Ghana. International journal of management sciences 3(3): $126-139$.

Olaniran, O. (2003). Mortgage banking: principles, policies and strategies, Osogbo, Nigeria, Newdeal publications (nig) Ltd.

Osibogun, D. (2016). Rething Nigeria's Mortgage Financing Policies for sustainable development and global competitiveness of the chartered institute of Banking of Nigeria.

Oyalowo, B.A (2012). Housing market constrains in the West Africa Region. Mediterranean Journal of Social Sciences, 3(II): 241-252 
Rust, H. (2012). The importance of housing finance in financial sector development in Africa. Centre for Affordable Housing Finance in Africa, a division of FinMark Trust.

Sanusi, J.O (2003) Mortgage finance in Nigeria: issues and challenges. Being text of a paper presented at the $9^{\text {th }}$ John Wood Ekpenyong memorial lecture, organized by the Nigerian Institution of Estate Surveyors and Valuers, January 29

Weiss, N.E. \& Jones, K. 2017. An overview of housing finance system in the United States. CRS Report, Congregational Research Service retrieved from www.crs.gov.

Yinusa, O.G., Ilo, B.M. \& Elumah, L. (2017), Mortgage financing and housing development in Nigeria Oshgbo Journal of Management 2(1): 57-67. 